\title{
Research on practical teaching of virtual reality integration of Engineering Management major from the perspective of New Engineering
}

\author{
Luo Lijuan ${ }^{1, a}$ \\ ${ }^{1}$ Xi'an FanYi University Xi'an, China 710105
}

\begin{abstract}
Absrtact. Starting from the practical significance of "New Engineering" to the practical teaching reform of engineering management specialty, this paper analyzes the current situation of practical teaching of engineering management specialty, expounds the construction ideas of practical teaching system of virtual and real integration of engineering management specialty from the perspective of new engineering, and puts forward the integration of practical teaching content, construction of virtual and real integration practice teaching platform and diversified evaluation system, so as to improve young teachers Engineering practice ability and other safeguard measures. Practice shows that practice teaching is the main channel to cultivate engineering practice ability and core competitiveness of engineering management students.
\end{abstract}

\section{INTRODUCTION}

China's one belt one road, 2025 manufacturing and Internet plus major strategies have been put forward. China's engineering education has responded positively, and has advocated the construction of new engineering courses, calling on universities to cultivate more innovative engineering talents with strong sense of innovation and practical ability to meet the industrial needs. "Fudan consensus", "Tianda action", "Beijing Guide" and other programmatic documents have pointed out the direction of China's engineering education reform and helped build a powerful country in higher education. Under the guidance of the overall direction and macro thinking, it is necessary to study the implementation scheme of accurate landing based on the specific characteristics of the specialty and the advantages of school resources.

Engineering Management specialty is a new interdisciplinary subject of engineering technology and management. It is to cultivate the comprehensive development of morality, intelligence, physique, beauty, labor, etc., to meet the needs of regional economic and social development, master civil engineering technology, basic knowledge of management, economy and law related to Engineering Management, and basic skills of modern engineering project management, with noble professional spirit and strong social spirit With a sense of responsibility, strong ability of rapid learning and innovation and practice ability, they can be engaged in engineering production and construction, project management decision-making, real estate operation and development, investment and cost work in the civil engineering production line after graduation. As an important teaching link of Engineering Management specialty, practice teaching plays a very important role in improving students' professional skills, overall quality and ability, as well as cultivating students' management ideas and innovative practical ability. Improving the effectiveness of practical teaching is one of the key links in improving the new engineering teaching.

\section{ANALYSIS ON THE CURRENT SITUATION OF PRACTICE TEACHING OF ENGINEERING MANAGEMENT SPECIALTY}

\subsection{Emphasizing theory over practice}

First of all, in the course system of engineering management, theory is the main part, practice is auxiliary, and practice is attached to theory. The practice teaching system is mainly composed of the practice part of professional education platform courses (professional basic courses, professional core courses, professional limited elective courses, professional optional courses, etc.) and centralized practical teaching courses (social practice, professional cognitive practice, production practice, graduation practice, graduation design, etc.), and the theoretical class hours are greater than the practice hours. Secondly, the arrangement of practice content does not fully consider the skill requirements of engineering practice for students. The verification experiment is the main method, and the design of comprehensive experiment is less, which is not conducive to the cultivation of students' free innovation and practice ability. 
On the one hand, the centralized practice teaching course is a mere formality, on the one hand, it is due to safety factors, on the other hand, the students' practice time is limited, so it is impossible to track one of them in the whole process Project. it is difficult to fully understand the technology applied in the whole project, only part of the construction content can be understood. Finally, in terms of the allocation of teachers, practical teachers are basically theoretical teachers, with little experience in engineering practice, which is not conducive to the development of practical activities. The above are the reflection of weak practical consciousness of the administrative departments of education, teachers and students.

\subsection{Backward practice facilities}

The lab and training room of Engineering Management specialty has more hardware and software facilities, but the advanced nature is not enough, the sharing is poor, the utilization rate is not high, the opening is not enough, and the hardware and software facilities are not updated in time to keep up with the needs of the times. For example, the engineering software training room is an important training room for training Engineering Management students' application skills. The training room is equipped with three good building simulation software. With the rapid development of construction industry and the rise of BIM Technology, BIM related software needs to be constantly improved to keep pace with the times. In addition, the administrator of the experimental training room has low professional quality and often fails to properly maintain the instruments and equipment, which is easy to cause hardware aging and low software version. Moreover, when the software and hardware fail, they can not be repaired and handled in time. Therefore, the normal development of experimental training is delayed.

The construction depth of off campus practice training base is not enough, the operation effect is poor, and the level of school enterprise cooperation needs to be improved. Many enterprises are not willing to accept students to carry out internships on the construction site due to safety considerations. The off campus internship and training bases are mainly maintained by teachers' personal relationship. Even if students enter the construction site, they also observe the situation without going deep into the actual operation. As a result, the learning effect of students in the construction site is not ideal, and the cooperation between colleges and practice bases is not stable and cooperative Low level, did not achieve the goal of improving students' practical and innovative ability. In addition, due to the school's supervision and management of off campus internship is not in place, and the policy on off campus practice and training is not perfect, a team leading teacher should take into account the students in one class, which is easy to cause the phenomenon that the team leader is not enthusiastic, some teachers lead the students to practice and practice the training goal is not clear, cut down the practice content and compress the practice training time.

\subsection{The evaluation system is not perfect}

The lack of scientific evaluation criteria, single evaluation methods and forms lead to one-sided evaluation results. The evaluation of the effect of school practical training experiment ignores the process evaluation and pays attention to the final result evaluation. It mainly focuses on the quality and attendance of the experimental training report. In the case of homework plagiarism, the experimental report is generally condensed into 3 or 4 versions, which often leads to the students who "play soy sauce" with excellent results. This unfair evaluation result is just the unscientific evaluation standard The strong embodiment of the disadvantages of single evaluation method. Because of the particularity of off campus practice, the skills mastered by students in practice can not be considered one by one, which mainly depends on students' active learning. The subject of evaluation is single, and teachers play a leading role in the evaluation. The goal of taking students as the main body is formalized, ignoring the evaluation of other subjects such as employers. As a result, students only pay attention to the examination scores in the learning process, and do not pay attention to the improvement of comprehensive professional ability, so that it does not match the demand of social and economic development for talents.

\section{PRACTICAL TEACHING OF INTEGRATION OF VIRTUAL AND ACTUAL FOR ENGINEERING MANAGEMENT MAJOR}

Engineering Management major is a subject with strong practical application. According to the construction principle of "integration of virtual and real, can be real but not virtual", the practice teaching of engineering management specialty makes full use of the existing experimental training conditions, optimizes and adjusts the content of experimental training, and effectively introduces virtual simulation system to cultivate innovative talents with applied skills.

\subsection{Integration of experimental training content}

Engineering Management major should actively meet the needs of local economic and social development and enterprise technological innovation, grasp the direction of industry talent demand, integrate experimental training content pertinently, and set up three-level modules of basic type, design type and comprehensive innovation type (see Table 1), so as to improve students' engineering application ability step by step, promote the close combination of talent training and industrial demand, and cultivate talents with high quality Innovative engineering and technical personnel with international vision. The three levels are divided into three levels: first, from the perspective of curriculum continuity, the basic type refers to the corresponding practice parts of professional basic courses, professional core courses, professional optional courses and professional limited elective courses; the design type and comprehensive innovation type refer to 
centralized practical teaching, college students' innovation and Entrepreneurship, subject competition, holiday teaching practice, extracurricular expansion activities, etc.; the second is from the difficulty of experimental training content From the perspective of ease degree, basic type refers to the skills that Engineering Management students must master, mainly based on the verification experiment, and consolidate relevant theoretical knowledge. Design type and comprehensive innovation type are based on the completion of basic type to complete the design, implementation and summary of a small project, such as the preparation of bidding documents for a project, digital topographic mapping of a certain area, and three aspects of a plant area The construction of dimension model is used to test the students' comprehensive application ability, innovation ability, team cooperation ability, coordination and communication ability, etc. In the arrangement of experimental training content, we should pay attention to the combination of virtual reality and reality. If the school has relevant instruments and facilities, we should not adopt the virtual simulation system, let the students use the corresponding facilities to complete the experimental training, so that students can achieve zero training after graduation. For the construction content with low safety factor and space-time conditions, advanced virtual simulation is introduced System, such as BIM software, students can master the corresponding skills by operating in the virtual system, and BIM Technology is of great significance to reduce investment and improve construction quality.

TABLE 1 Types Of Experimental Training Contents Of Engineering Management Specialty

\begin{tabular}{|c|c|c|}
\hline Basic Type & Design Type & $\begin{array}{l}\text { Comprehensive } \\
\text { Innovation Type }\end{array}$ \\
\hline $\begin{array}{c}\text { Tensile } \\
\text { compression test of } \\
\text { low carbon steel; } \\
\text { Understanding and } \\
\text { use of total } \\
\text { instrument; } \\
\text { Water consumption } \\
\text { experiment of } \\
\text { cement standard } \\
\text { consistency, etc. }\end{array}$ & $\begin{array}{c}\text { Construction } \\
\text { organization design; } \\
\text { Preparation of } \\
\text { bidding documents; } \\
\text { Valuation with } \\
\text { bill of quantities; } \\
\text { Feasibility study } \\
\text { report, etc }\end{array}$ & $\begin{array}{c}\text { Digital } \\
\text { topographic } \\
\text { mapping; } \\
\text { Green } \\
\text { reconstruction of } \\
\text { teaching building } \\
\text { roof; } \\
\text { Durability test of fly } \\
\text { ash. }\end{array}$ \\
\hline
\end{tabular}

\subsection{Construction of practical teaching platform of virtual reality integration}

The on-site experimental teaching platform and virtual experimental teaching platform are constructed. The onsite experimental teaching platform is composed of on campus experimental training room and off campus practice training base.

For the experimental training room in the school, we should build soil mechanics laboratory, building materials laboratory, engineering mechanics laboratory, descriptive geometry model exhibition room, engineering drawing training room, engineering project management sand table training room, engineering cost application software training room and other necessary experimental training rooms for engineering management specialty. At ordinary times, we should strengthen the update and maintenance of existing instruments and equipment, according to the industry Development trend and emerging technology, timely purchase and improve engineering software, to ensure the progress with the times. Expand the scale of the laboratory in a planned way to ensure the increasing demand of students for practical training. We should strengthen the opening of experimental training room, encourage students to use their spare time to develop and design experimental training projects in the experimental training room, and cultivate students' active learning consciousness, practical ability and innovative spirit.

For the construction of off campus practice and training base, we should deepen the integration of production and education, school enterprise cooperation, collaborative education, enhance students' employment and entrepreneurship ability, and cultivate a large number of application-oriented and technical skilled talents with strong industry background knowledge, engineering practice ability and competent industry development needs. On the one hand, expand the scope of school enterprise cooperation, actively sign cooperation agreements with cost accounting firms, consulting companies, auditing, construction enterprises and other units to meet the practical needs of students in different professional directions. On the other hand, we should strengthen the depth of school enterprise cooperation, appropriately increase the investment in school enterprise cooperation based on the principle of mutual benefit between school and enterprise, sign stable long-term cooperation agreement with enterprises, and form a "multi-level, multifunctional, open-ended, internal and external combination" training base to ensure the quality of students' off campus practice. Invite enterprises to participate in the construction of engineering management professional course practice link, put forward opinions on the cultivation of talents' practical ability from the perspective of enterprise demand, employ production line engineers to guide practical training; at the same time, recommend excellent graduates for enterprises, save the cost of human resources of enterprises, and select some teachers to take part in temporary training in the training base, so as to realize the win-win situation between enterprises and schools.

The construction of BIM Technology Based Engineering Management Comprehensive Experiment virtual teaching platform, BIM based engineering project life cycle management simulation, covering the early stage of project decision-making, construction design, physical construction, later operation and maintenance stage, comprehensive skills, knowledge cohesion and continuity, help to cultivate students' engineering ability in all aspects, so as to enhance the core competitiveness of occupation. BIM virtual simulation training platform includes building structure design, construction process, project cost, project management and other sub platforms. The content is rich, and the knowledge display is visualized and lifelike. In the laboratory, students can master the relevant knowledge of the construction site, especially for some projects with low safety coefficient, which can not be completed at the construction site, can be completed in the laboratory The problem that students can't really go deep into the engineering link during the construction site practice and 
training, the virtual simulation system based on BIM Technology provides the possibility, students can operate according to BIM software in the laboratory, and can understand the full cycle implementation steps of construction project in detail, and the depth and breadth of professional knowledge are guaranteed.

BIM electronic bidding competition, BIM construction project management application skills competition, construction simulation application skills competition and other disciplines competition, (provincial level - national level) college students' innovation training project, (school level - provincial level - national level) Internet plus project, research project is an important platform to enhance the innovative ability of University students, and the virtual simulation system based on BIM technology is The construction of the platform provides hardware and software support.

Surveying and mapping technology and instruments update quickly. There are many kinds of surveying and mapping instruments and limited college funds. As it is non-surveying and mapping engineering specialty, the investment in surveying instrument and equipment is relatively limited. It is impossible to purchase all instruments on the market. Different surveying and mapping units will choose and purchase urgently needed surveying instruments according to their own economic basis and work needs. It is very difficult for students to get started as soon as possible in the measuring post only through the training of measuring instruments in the "engineering measurement" laboratory. Therefore, it is necessary to familiarize students with as many measuring instruments as possible through online means.

\subsection{Improving young teachers' engineering practice ability}

As soon as they graduate, young teachers in Colleges and universities are engaged in teaching work as practical teaching instructors. They have no experience in the construction line and lack of practical experience. They are often on paper. It is imperative to improve the practical ability of young teachers. With the help of school enterprise cooperation platform, teachers can be encouraged to use the winter and summer vacation to go to the construction site, or the school can give policy support, so that young teachers can rely on personal contacts to find the corresponding construction enterprises or go to the construction enterprises with cooperative relations with the school to work for a year. In addition, we should increase the intensity and density of short-term training for young teachers, invite enterprise personnel into colleges and universities to give teachers advanced construction software and hardware training, help teachers have advanced skills, encourage teachers to sacrifice weekends to participate in various professional skills training, and give financial support and policy inclination. The college pay attention to the training of double qualified teachers, especially increase the construction of "double qualification" teachers who are familiar with BIM Technology, and give certain financial rewards to teachers who have obtained corresponding professional qualification certificates (first-class construction engineer, structural engineer, registered surveyor, cost engineer, certified public accountant, economist, etc.) and those who have worked in construction enterprises for more than one year, so as to encourage teachers to improve Their own skill level. In practice, we should implement the tutorial system in which the old bring the new and have practical experience without practical experience, give full play to the advantages of internal talent resources, and improve the skill level of the overall teaching team.

\subsection{Construction of diversified evaluation system}

According to the skill requirements of the talent market for Engineering Management professionals, the top-level design engineering management experimental course group, lists the skills that engineering management graduates should have when they graduate, and evaluates the achievement degree with this goal. In the assessment, both skill assessment and quality assessment are taken into consideration. Instead of the previous single assessment and evaluation method, process evaluation is carried out, and diversified evaluation methods such as training operation, internship reply, group report, training report, scheme design, document preparation, feasibility report, attendance and team cooperation ability are flexibly adopted. The construction of schools, teachers, employers and other diversified evaluation subjects, through different evaluation subjects from different angles to make a comprehensive and objective evaluation of students. This paper uses a variety of evaluation methods, including qualitative evaluation and quantitative evaluation, formative evaluation and summative evaluation, online and offline, to comprehensively and objectively reflect students' skill level. In addition, we should establish a longterm follow-up research mechanism, collect the feedback information from employers and revise the evaluation system in reverse.

\section{CONCLUSION}

Under the background of new engineering, the economic and industrial structure has changed, which puts forward new and higher requirements for engineering talents. It requires that engineering and technical personnel can adapt to and meet the development needs of the new economy in the future, and have more solid basic knowledge, stronger practical ability, innovation ability, international competitiveness and the ability to solve complex engineering problems. The practice teaching of Engineering Management specialty is an important link to stimulate college students' innovative potential and analyze and solve complex engineering practical problems. The college must be based on the characteristics of Engineering Management and based on the demand for talents in future construction projects, the practical teaching system of "innovation, openness, systematization and foresight" should be constructed to encourage students to enter the experiment actively and frequently only by going deep into the construction site and continuously enhancing the 
engineering consciousness can the students' innovative consciousness be effectively stimulated and cultivated, and the applied skilled talents meeting the needs of the engineering construction industry can be cultivated.

\section{Author}

Corresponding author: Luo Lijuan (1986 --), female, master, lecturer, studies in Higher Education. E-mail: khknudxnt@163.com

\section{ACKNOWLEDGMEN}

I would like to express my sincere thanks to Engineering Management experimental teaching demonstration center of Xi'an FanYi University in 2019 (Z1901) and The second batch of collaborative education projects of the Ministry of education in 2018 (201802132059) for their financial support for this paper.

\section{REFERENCES}

1. Lu Xin, Ren Liyong. Exploration of curriculum practice teaching mode based on OBE engineering education concept $[\mathrm{J}]$. Experimental science and technology, 2018,16 (6): 107-111,116. (in Chinese)

2. Li Chunmei, he Hong, Li Yuan, et al. In depth study on the experimental teaching system of "virtual and real complementary" for materials Majors under the background of new engineering. [J]. Journal of Southwest Normal University (NATURAL SCIENCE EDITION),2020,45(4):143-148. (in Chinese)

3. Zhang Dongyan, Zong Yongchen, Wang Peiqing. Research on the construction of practical teaching system for engineering management major -- Taking Tibet agriculture and animal husbandry University as an example. [J]. Journal of higher education,2020,(28). (in Chinese)

4. Wei Fuxiang, Wang Yanqing, Liu Hongtao, et al. Exploration of practical teaching system of materials specialty under the background of "new engineering course". Laboratory research and exploration,2019, 38(1):197-200. (in Chinese)

5. Liu Haibo, Shen Jing, Wang Gesi, et al. Construction of virtual simulation experiment teaching resource platform from the perspective of engineering education. [J]. Exper-imental technology andmanagement,2019,36(12):19-22,35. (in Chinese) 